\title{
The Inheritance Rights of a Foreign Citizen Child of an Indonesian Mother in the Perspective of Private International Law (Review of the Decision Number 141/G/2010/PTUN-JKT jo. Decision Number 863/2011/PTUN-JKT jo. Decision Number 28K/TUN/2011 jo. Decision Number 105 PK/TUN/2013)
}

\author{
Cut Memi ${ }^{1}$ \\ \{cutmemi@gmail.com ${ }^{1}$ \} \\ Lecturer at Law Faculty of Tarumanagara University, S. Parman Street No. 1, Grogol, Jakarta Barat ${ }^{1}$
}

\begin{abstract}
In the event that a different nationality marriage occurs, it is related to several aspects of International Civil Law because the marriage relationship contains foreign elements. On the other hand, it creates differences in nationality between children born from marriage and fathers or mothers who are Indonesian citizens, which also raises legal problems. The method used in this study is the normative legal research method. Based on the Decision Number 1416/2010/PTUN.JKT, the State Administrative Court has taken a final decision by stating that Sunnesh Rattan Laddaram is not entitled to his mother's inheritance. Even more, the verdict was then upheld to the stage of Judicial Review in the Supreme Court referring to the Decision Number 105/PK/TUN/2013. Upon further analysis, the judge's verdict indeed in this case is contrary to the rights of the child, the personal status theory, the preliminary issue, as well as the legitimate portion "legitieme portie" theory contained in the private international law. As a result, the researcher would strengthen the private international law theories and recommend that the judges of Jakarta Administrative Court implement the private international law theories in the future decision making and Sunnesh may submit the decision request as a heir to the District Court to gain his inheritance rights.
\end{abstract}

Keywords: Inheritance Rights of A Child, Law of Inheritance, Marriage between Different Citizenship.

\section{Introduction}

\section{A. Background}

Mixed marriage between Indonesian citizens and foreigners is an undisputed fact that happens in Indonesia. This mixed marriage has raised the issue in the Private International Law since foreign elements are fulfilled in this marriage. Indonesian Law No. 1 of 1974 concerning Marriages defines that a mixed marriage is the marriage between two persons subject to different family law as well as different citizenship and one of the parties holds 
Indonesian citizenship. Therefore, mixed marriage is subject to Private International Law which is governed in Algemeene Bepalingen van Wetgeving (AB). Article 16 of $\mathrm{AB}$ stipulates that: "De wettelijke bepalingen betreffende den staat en de voegdheid der personen blijven verbindend voor ingezetenen van Nederlandsch-Indie, wanneer zij zich buiten's land bevinden" (The provisions of law concerning the status and rights of a person are still valid although that person stays overseas). The status and rights in Private International Law are called personal status, which is every act in family law that includes: marriages, divorces, inheritance, etc. Based on that, if there is an issue of personal status, it will be settled by the rules in Private International Law.

On the other side, as stipulated in Article 4 point $\mathrm{c}$ and $\mathrm{d}$ of Act No. 12 of 2006 concerning Citizenship, children born within legal wedlock from an Indonesian father and mother, as well as from an alien father and an Indonesian mother are both citizens of Indonesia. Pursuant to Article 6 of Citizenship Act, those provisions will affect in the dual citizenship of the child. Upon fully reaching the age of 18 (eighteen) or upon marriage, the child shall choose one citizenship.

Based on that reason, children born out from a mixed marriage could comply with the citizenship of its mother or father until it fully reaches the age of 18 (eighteen). When the child fully reaches the age of 18 (eighteen), the child will need to choose to comply with the citizenship of its mother or father. With such provision, there is a chance that the child will have a different citizenship from its parents when the child fully reaches the age of 18 (eighteen), which could raise a legal issue related to the inheritance rights of an alien child to its Indonesian mother. Meanwhile, according to Article 21 section 1 of Act No. 5 of 1960 concerning Basic Agrarian Principles, "Only Indonesian citizens can have the rights of ownership/freehold." Hence, the Indonesian laws related to inheritance shall not be applied to that child.

One of the sample cases, which is also the main focus in this research paper, is the case of Sunesh Rattan Laddaram (a son who holds British citizenship) who struggles to obtain his inheritance rights from his Indonesian mother. Sunesh Rattan Laddaram is a son of a mixed marriage between his mother, Swita Motiram, who previously held Indonesian citizenship and converted her citizenship to Indian citizenship, while his father, Rattan Ladharam, held British citizenship, in 1979. However, his parents divorced in 1990 and the father got the custody of the child. Sunesh, therefore, holds a British citizenship as his father does. After the divorce, Swita Motiram came back to Indonesia and converted her citizenship from Indian to Indonesian. On 3 November 2009, Swita Motiram passed away and left her inheritance. The siblings of Swita Motiram, Kamlesh and Johny Motiram, filed an inheritance rights application for the wealth or property left by Swita Motiram to the Property and Heritage Agency.

On that basis, the Property and Heritage Agency issued a Certificate of the Rights to Inherit Number W7.AH.06.10-8/II/2010 on 25 February 2010. After the Certificate of the Rights to Inherit was issued, Sunesh claimed to be the heir since he is the only son of Swita Motiram and filed an application for the property left by Swita Motiram to the Property and Heritage Agency. The Property and Heritage Agency, therefore, rectifies the previous certificate and nullify the Certificate of the Rights to Inherit Number W7.AH.06.10-8/II/2010, and declared that Sunesh Rattan Ladhanam as the heir of the inheritance left by Swita Motiram.

However, the siblings of Swita could not accept the declaration and postulate that Sunesh shall not have the rights to inherit since Sunesh is an alien and is not subject to Indonesian law. Eventually, they filed a lawsuit to challenge the Certificate of the Rights to Inherit 
Number W7.AH.06.10-8/II/2010 to Jakarta State Administrative Court with registered number 14/G/2010/PTUN-JKT. The Jakarta State Administrative Court decided to nullify the Certificate of the Rights to Inherit. Moreover, the decision of Jakarta State Administrative Court was strengthened at the judicial review based on the Judgment Number 105 PK/TUN/2013 at the Supreme Court of Indonesia, which resulted in the rights to inherit enjoyed by the son to be dismissed. This is a challenging issue, which the author, as an expert in Private International Law, is keenly interested in conducting a research on the topic as mentioned above.

\section{B. Issue}

The issue raised is in this research how are the rights to inherit of an alien child toward the inheritance of an Indonesian mother based on Private International Law?

\section{Objective of research}

The objective of this research paper is to conduct a research related to the rights to inherit of an alien child towards the inheritance of an Indonesian mother based on the perspective of Private International Law. This paper is not only expected to contribute, to either in theory or practice in Private International Law, to the judges as a basis in ruling the decision, but the rights to inherit of an alien child to the inheritance of an Indonesian mother as well.

\section{Literature Review/Discussion}

\section{The Definition of Inheritance}

Sudarsono, an expert of Inheritance Law, states that if someone has passed away, the rights and obligations of that person will be transferred to its heir. It is in line with Article 830 Indonesian Civil Code that inheritance takes place in case of death only. Meanwhile, the person who enjoys the rights to inherit is the husband, wife, children, or appointed person. ${ }^{1}$

Therefore, in inheritance matter, there are several terms that are related to each other, such as testator, a heir, and inheritance. ${ }^{2}$

a) A testator is a person who has passed away and left its inheritance.

b) A heir is a member of the family of the testator who replaces the position of the testator under inheritance law resulted from a death incident of the testator.

c) Inheritance is wealth, including all the assets and liabilities of the testator that will be transferred to the heir. All the assets and liabilities, which is joint-owned the heir, are called boedel.

d) Inheritance Law is law that governs what should be done with the inheritance of a person who has passed away and the consequences of the transfer of the inheritance from testator to the heir.

\section{Laws related to the Certificate of the Rights to Inherit Making}

\footnotetext{
${ }^{1}$ Sudarsono, Hukum Waris dan Sistem Bilateral, (Jakarta: Rineka Cipta, 1994), p. 15.

${ }^{2}$ Surini Ahlan Sjarif and Nurul Elmiyah, Hukum Kewarisan Perdata Barat, (Jakarta: Kencana, 2006), p. 7-10.
} 
A heir, although s/he is the biological child of the testator, does not mean that $\mathrm{s} / \mathrm{he}$ will definitely have the rights to inherit. Therefore, as stated by I Gede Purwaka ${ }^{3}$, it shall be equipped with the Certificate of the Rights to Inherit issued by officials or an authorized government department or made by the heir that is validated by the village head, urban village head, or subdistrict head. The description of the rights to inherit will be used as a strong evidence for the transfer of rights of inheritance from the testator to the heir. ${ }^{4}$ There are several regulations related to the Certificate of the Rights to Inherit, such as:

a. Letter of Director General of Religion on behalf of the Minister of Home Affairs dated 20 December 1969 No. Dpt/12/63/12/69 concerning Certificate of the Rights to Inherit and Proof of Citizenship;

b. Article 42 section 1 of Government Regulations No. 24 of 1997 concerning Land Registration;

c. Article 111 section 1 point c Head of National Land Authority Regulation No. 8 of 2012 concerning the Implementation Provisions on Law No. 24 of 1997 concerning Land Registration.

Based on those regulations, the evidence letter that could be submitted as a heir are: a) the testament of the testator, or b) court ruling, or c) the determination by the judges. Meanwhile, the departments that have the authority to issue the Certificate of the Rights to Inherit, are distinguished based on the category of the citizen, which are:

1. As for indigenous Indonesian: the Certificate of the Rights to Inherit will be made by the heir/s witnessed by 2 (two) persons and validated by the village head, or subdistrict head in the domicile of the testator in time s/he passed away;

2. As for Chinese Indonesian: Certificate of the Rights to Inherit will be issued by Public Notary, meanwhile for Alien Orientals, besides Chinese: the Certificate of the Rights to Inherit will be issued by Property and Heritage Agency.

By relating it to the case of Sunesh, since Sunesh's mother (testator) belongs to Alien Oriental (not Chinese), therefore the Certificate of Rights to Inherit shall be issued by Property and Heritage Agency.

3. Elements in Inheritance Law

Basically, a person shall enjoy the freedom to do anything toward its wealth or property, including transferring or granting it to any person s/he prefers. This element is called individual element, however, the freedom in this context does not mean an absolute freedom, there are still restrictions by the laws. The restrictions is called legitime portie (legitimate portion), which means a particular part or an absolute part enjoyed vertically by the heir that shall not be set aside by the testator. It should be noted that wife (husband), relatives like uncle (aunt) do not enjoy the right of legitime portie. ${ }^{5}$

4. Inheritance Methods ${ }^{6}$

There are 2 (two) methods to be inherited:

a. Inherited by $A b$ intestato (inherited based on law)

\footnotetext{
${ }^{3}$ I Gede Purwaka, Keterangan Hak Mewaris yang Dibuat oleh Notaris Berdasarkan KUHPerdata, (Jakarta: Rajawali Press, 2003), p. 5.

${ }^{4}$ Ibid.

${ }^{5}$ Ali Afandi, Hukum Waris, Hukum Keluarga, dan Hukum Pembuktian, (Jakarta: Rineka Cipta, 2004), p. 45 .

6
} 
b. Inherited by testament (inherited based on the testament)

By relating it to this research, the inheritance method imposed on the mother of Sunesh towards her child is categorized as an inheritance by Ab intestato where the most characteristics of the inheritance are bloodline relatives between the testator and the heir.

5. General Principles of Inheritance ${ }^{7}$

a. In principle, the objects of inheritance is the rights and obligations in the field of property.

b. If death occurred, the rights and obligations of the testator will be immediately transferred to the heir(s) (saisine rights), which means that even without handover, the heir(s) immediately obtains the inheritance of the testator.

c. The parties having the rights to inherit are bloodline relatives to the testator. Based on far or close blood relationship, the first class of the heirs are children and its descendants, the longest living husband or wife, while the second class of the heirs are parents, siblings, and descendants from siblings. ${ }^{8}$

d. In principle, the inheritance shall not be left without distribution/division.

e. In principle, every person, including baby is competent to inherit, except those who are inappropriate to inherit (Article 838 of Indonesian Civil Code).

6. Theories of Private International Law Relating to Inheritance

\section{The Theory of Personal Status}

Before proceeding to discuss the personal status, firstly, it is required to explain the definition of Private International Law. Private International Law is a law, particularly civil law, that has the nature of international, but the sources of law are still national laws. Why it is international by nature because there are foreign elements in the civil relations. Nevertheless, the sources of law are still national laws. There are 2 (two) systems of law in determining the personal status of a person, one is common law system that applies the domicile principle, and another is civil law system that applies the nationality principle.

Historically, Indonesia enjoys the civil law systems and applies the nationality principle in determining the personal status of her citizens, in other words, the determination of the personal status of a person is determined by its nationality. Furthermore, concerning the personal status, it is required to explain whether or not the wealth or property owned during the marriage is included in personal status. The precedents of Indonesia determine that the wealth or property is included in the personal status. ${ }^{9}$ Therefore, since Indonesia applies the nationality principle, hence, in Private International Law governs that wealth or property is included in personal status and determined by the national law of the testator when it has passed away.

Based on that, wherever the Indonesian citizens go, Indonesian law, related to inheritance law, will always bind them. The author is still referring to Algemeene Bepalingen van Wetgeving $(\mathrm{AB})$ since, until now, there is no law that governs Private International Law in Indonesia. Hence, the issue of Private International Law will be settled by the laws, which is a legacy of Dutch colonization period.

\footnotetext{
${ }^{7}$ Surini, Ibid.

8 ...

${ }_{9}^{9}$ Sudargo Gautama, Hukum Perdata International Jilid III, bagian I, Buku ke-7, (Bandung: 2004), p. 25.
} 


\section{The Theory of Choice of Law}

Choice of law is a separated study in the general theory of Private International Law or usually called partij autonomie. ${ }^{10}$ Choice of law is a freedom given to the parties in determining or choosing which law will govern their contract, that has the international nature. The choice of law has been accepted based on the freedom of contract principle. Article 1338 section 1 of Indonesian Civil Code states that "All agreements that are made legally shall apply as the law between the parties thereto." "1

The freedom in choosing the law is based on the interest of the contracting parties in conducting their business that will be beneficial for them.

By choosing the law, the contracting parties will feel secured since the applicable law is the law choosen and approved together by the contracting parties.

However, the freedom of contract principle will not be applied in inheritance law. The choice of law will only be applied in contract law. Hence, the choice of law principle will not be applied in other law fields, including the inheritance law, in particular, the personal status.

\section{The Theory of Evasion of Law}

Besides the theory of choice of law, we find another theory which is related to this research, it is Evasion of Law. There are several terms of evasion of law:

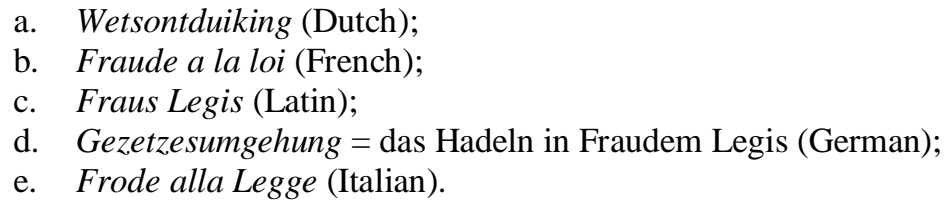

Evasion of law is an act conducted with the purpose of avoiding a requirement or certain legal consequence of a particular law to satisfy its purpose, as that person will be bound by a foreign law, not its national law (setting aside its national law). Therefore, the element of conducting evasion of law is avoiding a requirement or legal consequence of a particular law to satisfy its purpose. The objective is to be bound by foreign law (not its national law).

\section{The Theory of Preliminary Matter}

The theory of preliminary matter is a theory in Private International Law which states that in settling a Private International Law case, as a legal issue should be settled or determined first before the final decision made by the judges in a Private International Law. The premilinary matter arises, if the decision of a legal issue shall depend on the validity of the legal relation or other legal issues. Example:

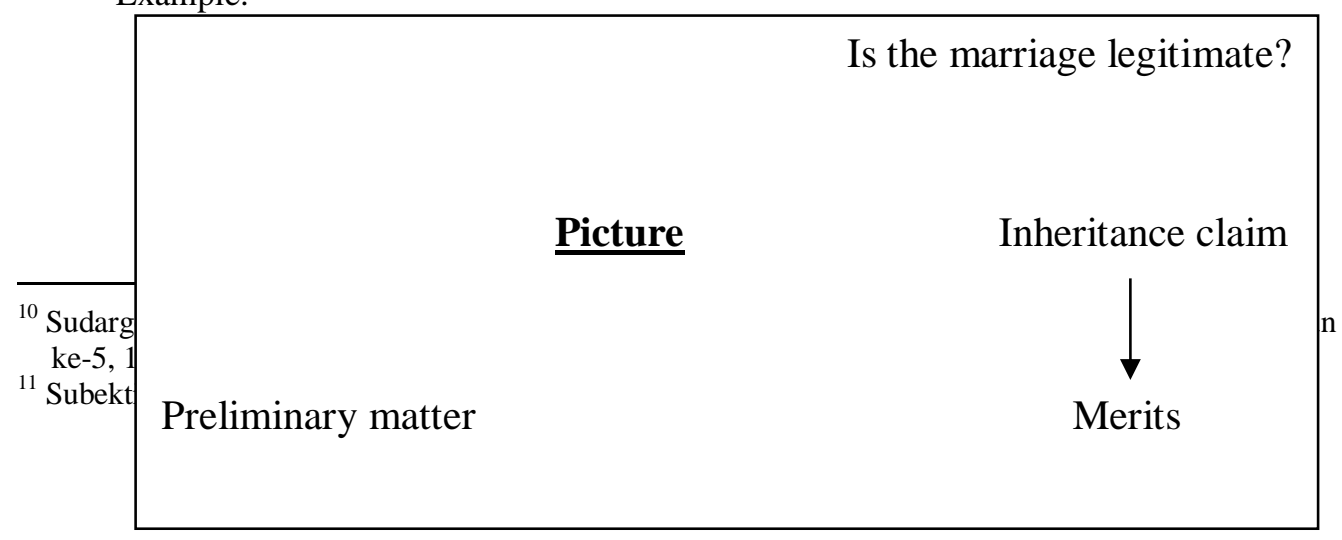




\section{Explanation of the picture:}

A woman married to a man and gave birth to two children (a son and a daughter). Years later, after the father of the children passed away and the children filed a lawsuit to claim the rights to intherit to the court. The claim, in this case, is called merits. In order to settle the merits, according to the Theory of Preliminary Matter, it shall examine the preliminary matter, in this case, if the mother has married to another person and has not divorced before marrying the father of the children, therefore, the marriage between her and the father of the children is not legitimate since the mother is still bound to the previous marriage. As the marriage is not legitimate, therefore, the children of them are children out of wedlock, hence, the merits could not be ruled.

Pursuant to the Theory of Preliminary Matter, if it applies to the inheritance case of Sunesh, before the judges decide the case, the judges shall firstly determine the validity of the preliminary matter (in this case whether or not the marriage between both parents of Sunesh are legitimate). Based on the validity of the marriage, the judges could determine the merits of the inheritance rights issue. Assuming the marriage is valid, the decision of the judges shall grant the rights to inherit to Sunesh. However, if it is otherwise, the decision of the judges shall nullify the Certificate of the Rights to Inherit.

\section{Result And Discussion}

The logical background of the rationale, as the basis, for the judges of State Administrative Court of Indonesia are stated infra:

a. Consider that the panel of judges agree that every descendant has the rights to inherit from its parent(s), however, the provision does not govern concerning the institution that has the authority to issue the Certificate of the Rights to Inherit in cassu to an alien who has Indonesian parent, who is a Foreign Oriental Group.

b. According to the consideration above, the panel of judges views that the Respondent, in issuing the Certificate of the Rights to Inherit No. W7.AH.06.10-36/VII/2010 on 19 July 2010 that has been given to Sunesh Rattan Ladharam, has acted beyond its authority.

c. By any reasons of the act of the Respondent, it shall be categorized as violating the Legal Certainty Principle, and Orderly State Officials Principle as a part of the Good Governance Principle. Therefore, based on the provision as stipulated in Article 53 Section 2 letter b of Law No. 9 of 2004 concerning the Amendment of Law No. 5 of 1986 concerning State Administration Judicature, the decision made by the Respondent relating to the dispute object shall be ruled as invalid, and also, the Respondent is entitled to revoke the disputed object that has been issued.

d. The president of the panel of judges, Dra. Marsinta Uli Saragih, S.H., M.H., expressed disagreement with the majority of judges by writing a dissenting opinion as stated below.

e. Because the Claimant used the invalid information that states Swita Motiran does not have a descendant in its rights to inherit application, it should be considered that the Certificate of the Right to Inherit No. W7.AH.06.10-08/II/2010 on 25 February 2010 contains the legal defect.

f. According to the consideration above, the president of the panel of judges argued that the Claimant does not have the interest in filing the lawsuit to the Jakarta State 
Administrative Court and therefore, the Court shall reject the claim of the Claimant and based on Judgment No. 141/G/2010/PTUN.JKT.

Eventually, the judges ruled and adjudged that: declare that the Certificate of the Right to Inherit No. W7/AH.06.10-36/VII/2010 on 19 July 2010 that was given to Sunesh Rattan Ladhram, held by the Respondent, is invalid.

For that reason, Sunesh was not satisfied with the judgment. Later on, the Chairman of Property and Heritage Agency and Sunesh Rattan Ladharam filed an appeal application to Jakarta State Administrative High Court. The rationale of the judges of the Jakarta State Administrative High Court in judging the case are stated infra:

a. In responding to the panel of judges of State Administration Court first degree, the panel of judges of State Administrative High Court disagrees to the logical background of the judgment by the State Adminstrative Court first degree, reasoned by: pursuant to the law principle of government administration, the official who made a decision has the authority to revoke or rectify it if there is a fallacy in making the previous decision.

b. The legal issue, in this case, is that the Certificate of the Rights to Inherit No. W7/AH.06.10-36/VII/2010 on 19 July 2010 concerning the Inheritance Rights to the Inheritance of Swita Motiram only states that Sunesh Rattan Ladharam as the only heir of Swita Motiram. Is the act of Respondent/Appellant in issuing the disputed object justified by the law?

c. Regarding to the law considerations relied by the Respondent/Appellant in issuing the disputed object a quo, the panel of judges of Jakarta State Administrative High Court argued that the reasons of the Respondent/Appellant are the reason of civil, which shall not be so easy to nullify or rectify the first decision which is the certificate issued on 25 February 2010 No. W7.AH.06-10-08/II/2010. Hence, substantially, the disputed object was issued not in accordance with the laws and shall be nullified.

Eventually, by the Judgment No. 86/B/2011/PT.TUN.JKT, the judges declared:

a. The nullification of the decision of the Respondent/Appellant No. W7.AH.06.1036/VII/2010 on 19 July 2010 concerning the Certificate of the Rights to Inherit that was given to Sunesh Rattan Ladharam.

b. Obligate the Respondent/Appellant to revoke the decision of Respondent/Appellant No. W7.AH.06.10-36/VII/2010 on 19 July 2010 concerning the Certificate of the Rights to Inherit that was given to Sunesh Rattan Ladharam.

After that, the Property and Heritage Agency of Jakarta and Sunesh Rattan Ladharam filed a cassation lawsuit to the Supreme Court. The rationales of the judges of the Supreme Court in judging the case are stated infra:

a. The rationale of cassation lawsuit could not be justified since there is no error of Judex Factie in applying the law, on the basis of the Decision of State Administration Disputed object to evaluate and examine the civil right based on Article 14 Section 1 of Instructie Voor De Gouvernements Landmeters STBL 1016 No. 517 as the authority of the Property and Heritage Agency as the jurisdiction of the general court. Besides, the Respondent has acted beyond its authority since the act of the Respondent is inconsistent with the Principle of Legal Certainty, and Orderly State Officials Principle as a part of the Good Governance Principle.

b. The issuance of the disputed object is inconsistent with the law, and violates the General Principles of Good Governance (Principle of Legal Certainty), the Respondent relied on the civil reasons and nullified the previous decision that states two heirs, while in the 
disputed object only states one heir, and also the objections regarding the assessment of the result of the evidence which is an appreciation of a reality, which could not be considered at the cassation stage since the examination at cassation is only related to the error in applying the law, as stipulated in Article 30 of Law No. 14 of 1985 concerning Supreme Court as amended to Law No. 5 of 2004 concerning Supreme Court and second amendment to Law No. 3 of 2009 concerning Supreme Court.

c. Based on those reasons above, the judgment of Judex Factie, in this case, is not inconsistent with laws and/or regulations. Therefore, the cassation application submitted by the Cassation Applicant I: Sunesh Rattan Ladharam and Cassation Applicant II: the Chairman of the Jakarta Property and Heritage Agency shall be rejected.

On 9 May 2012, State Administrative Supreme Court, by its judgment No. 28/K/TUN/2012, ruled and adjudged: Reject the cassation application of the Cassation Applicant I: Sunesh Rattan Ladharam and Cassation Applicant II: Chairman of Jakarta Property and Heritage Agency.

Since Sunesh, once again, was not satisfied with the judgment, Sunesh and the Jakarta Property and Heritage Property filed a judicial review application to Supreme Court. The rationales of the judge at the judicial review stage are stated infra:

a. The judgment of Judex Juris is appropriate since there is no fallacy and also there is no falsehood or craftiness from the opposing party as mentioned in Article 67 letter $\mathrm{f}$ and a of Law No. 14 of 1985 concerning Supreme Court as amended to Law No. 5 of 2004 concerning Supreme Court and the second amendment to Law No. 3 of 2009 concerning Supreme Court.

b. In order to examine the civil rights in the disagreeing condition or containing the order element, it becomes the authority of the general court.

c. Based on the rationales above, therefore, the judicial review application submitted by the Judicial Review Applicant: Sunesh Rattan Ladharam is not reasonable and shall be rejected.

Eventually, on 1 October 2013, the Supreme Court, by its judgment No. 105/PK/TUN/2013, ruled and adjudged: Reject the judicial review application from the Judicial Review Applicant, Sunesh Rattan Ladharam.

With regards to the judgment as stated above, with all due respect, the author disagrees with the judges. The considerations by the judges in stating that there are no rules that govern the institution that has the right to issue Certificate of the Rights to Inherit for an alien who has Indonesian parent/s and who is a Foreign Oriental Group, is fallacious and baseless since there are laws that govern it. According to Article 14 section (1) Instruksi Voor de Gouvernements Landmeters in Stbl. 1916 No. 517, jo. the Letter of Ministry of Home Affairs dated 20 December 1969 Number: DPT/12/63/12/69 jo. Regulations of the State Minister of Agrarian Affairs/ Chairman of the National Land Agency No. 3/1997 concerning the Implementing Provisions of Government Regulation No. 24/1997 on the Land Registration, it has been explicitly governed that the Certificate of the Rights to Inherit for an Indonesian, who is the Foreign Oriental Group descent, shall be issued by the Property and Heritage Agency. The panel of judges, in this case, has incorrectly applied the law and misinterpreted the inheritance rights enjoyed by an alien, whereas the law that shall be applied in inheritance is the law of the testator, not the law of the heir. The testator (the mother of Sunesh) is an Indonesian Foreign Oriental Group (not Chinese). Therefore, based on the law stated above, the act conducted by the Property and Heritage Agency in issuing the Certificate of the Rights to Inherit to Sunesh is in accordance with the law since the institution has the strong authority to do so. 
Further, relating to the issue, we must note that Indonesia is a civil law country that applies the Principle of Nationality in determining the personal status of a person, including the inheritance issue. Based on the principle, the law that applies, in this case, shall be the law of the testator, at the time of his/her mortality. Related to the present case, since the mother of Sunesh is an Indonesian at the time of her mortality, therefore, the Indonesian Civil Code shall determine whether or not Sunesh deserves the rights to inherit. Article 852 of Indonesian Civil Code stated that: "The children or their descendants shall inherit from their parents, grandparents, or further blood relatives in the ascending line, without distinction between those of different sex or age, notwithstanding that they may have been conceived from several marriages."

The provision means to state that nationality shall not hinder a child to inherit, moreover, the nationality and inherit rights are both different issue and not relevant one to another since the inheritance rights are determined by the bloodline, not the nationality, and the children are the first class that has the rights to inherit from their parents. ${ }^{12}$

However, there are laws that restrict the ownership rights of an alien in Indonesia. Article 21 section (1) jo. section (4) of Law No. 5 of 1960 concerning the Basic Regulation on Agrarian Principles that states only an Indonesian citizen may have rights of ownership. However, Article 21 section (3) of Agrarian Law states that any foreigner, who after the coming into force this Act has obtained the rights of ownership through inheritance, without a will or through communal marital property and any Indonesian citizen too, having the rights of ownership and losing nationality after the coming into force of this law, are obliged to relinquish that rights within a period of one year after the obtaining of that rights or after losing that nationality. If after expiry of that period the rights of ownership is not relinquished, then it becomes invalid by the provision that the rights of other parties, incumbent hereon, endure.

Based on that provision, an alien child is allowed to receive the inheritance, not to mention that the inheritance came from his biological mother. Therefore, the limitation of inheritance rights shall not be the obstacle for the inheritance rights of a child in receiving the inheritance from its mother since the law itself gives a solution without violating the rights of an alien child. Hence, the child shall still obtain the inheritance although he has different citizenship with his mother.

It shall also be noted that in civil law system, there is a principle known as legitime portie "legitimate portion" (absolute part) in determining the rights of the heir in gaining a part of the wealth that could not be diminished, even though there is a testament from the testator. As a civil law country, this principle is not only recognized in Indonesia, but other countries as well, such as France and England in the inheritance case of Annesley. Annesley is an English citizen domiciled in France. In 1919, she made a testament that excluded his son to inherit. The act of Annesley is lawful in England. However, although the case was judged by English judges, the judges actually settled the case by using French law, which is known as legitime portie, in governing the case. The judges adjudged and declared that the son of Annesley would have received the inheritance at the minimum portion, which is one-thirds of the inheritance. By relying on this case, Sunesh absolutely has the rights to inherit from his mother.

The most fundamental question that shall be addressed is the ideal decision in this present case. In International Private Law, there is a theory known as the Theory of Preliminary

${ }^{12}$ See Pitlo A, Hukum Waris Menurut Kitab Undang-Undang Hukum Perdata Belanda, Jakarta Intermassa, 1986, p. 41. 
Matter. This theory states that in settling an International Private Law issue, a legal issue, that should be settled or determined before the final decision by the judges in International Private Law cases. The preliminary matter arises if the decision of a legal issue depends on the validity of the legal relation or other legal issues. By applying this theory to the case of Sunesh, the core issue is the inheritance lawsuit, while, the preliminary matter is whether or not the marriage between both parents of Sunesh is legitimate. Based on the explanation by Sunesh in his lawsuit, Sunesh was born in a marriage between Swita Motiram and Rattan Ladharam, proven by the Certificate of Marriage No. 534375 issued by the Government of Hong Kong and has been legalized by the Embassy of Indonesia No. 6096 dated 10 December 1979. By relying on the evidence above, therefore, Sunesh is a child from a legitimate marriage. Because of the status of Sunesh as a child, the judges shall be able to settle the inheritance case. However, the judges, on the contrary, nullify the Certificate of the Rights to Inherit issued by the Property and Heritage Agency. The author disagrees with the judges since the Certificate of the Rights to Inherit held by the relative of Swita Motiram shall be considered null because it contains legal defect with no good faith by disguising the fact that Swita Motiram actually has a child, Sunesh, which caused the fallacious in applying the law.

All in all, the act of the Property and Heritage Agency in nullifying the Certificate of the Right to Inherit in the name of the relative of Swita Motiram is correct, and it is under the authority of the Property and Heritage Agency. However, the nullification of the Certificate of the Rights to Inherit in the name of Sunesh by the judges of the State Administrative Court, which is reinforced by the courts until the judicial review stage in Supreme Court, it has caused a "dead end" for a child who is pursuing his rights, particularly the inheritance rights from his biological mother. This clearly infringes the fundamental principles in the Declaration of Human Rights. Besides, another transgression by the judges is not giving any solution for both parties, instead, the judges give no certainty of law and fairness, in particular, to a child (Sunesh) who deserves to enjoy his rights.

\section{Conclusion}

Based on the research conducted, the author concludes that the alien child shall still enjoy the inheritance from his/her mother, who is an Indonesian. It is also supported by the theories of International Private Law in personal status, legitime portie theory, as well as preliminary matter theory. The judgment that nullifies the Certificate of the Rights to Inherit that was given by the Property and Heritage Agency to Sunesh is fallacious and baseless, it therefore could not be justified. This fallacy of judgment is expected not to happen again in the future. The judgment or decision of the judges has caused the fallacious in applying the law, it is caused by the judges' inadequate understanding in the theories of International Private Law. The act of the judges is inconsistent with the legal certainty and fairness principle, and infringed the fundamental principles in the Declaration of Human Rights.

The author recommends the judges in state/district courts to implement the theories of International Private Law, as the basis, to render a case that contains foreign elements in the future.

\section{Bibliography:}

Book: 
[1]. Ali Afandi, Hukum Waris, Hukum Keluarga, Hukum Pembuktian, PT. Rieneka Cipta, Jakarta, 2004.

[2]. BPHN Departemen Kehakiman, Naskah Akademik Peraturan Perundang-undangan tentang Balai Harta Peninggalan, Jakarta, 1995.

[3]. J. Satrio, Hukum Waris, Alumni Bandung, 1992.

[4]. Pitlo A, Hukum Waris Menurut KUH Perdata Belanda Jilid I, Jakarta Intermassa, 1986.

[5]. Sudargo Gautama, Pengantar Hukum Perdata Internasional Indonesia, Bandung Alumni, 1988.

[6]. _ Hukum Perdata Internasional Indonesia, Jilid III Bagian I buku ke-7, Bandung Alumni, 2004.

[7]. Surini Ahlan Sjarif dan Nurul Elmiyah, Hukum Kewarisan Perdata Barat, Prenada Media Group, Jakarta, 2006.

\section{Journal:}

[1]. Obbie Afri, Gultom. Fungsi, Tugas dan Peran Balai Harta Peninggalan Dalam Kewarisan. www.gultomlawconsultants.com, 03 Juli 2014

[2]. Tanjung Fathia Nadia, Kedudukan Anak Dalam Perkawinan Campuran Ditinjau dari UndangUndang Nomor 1 tahun 1974 dan Undang-Undang Nomor 12 tahun 2006 tentang Kewarganegaraan, Sumatera: FH Sumatera Utara, 12 Februari 2016.

[3]. Wijayanto Setiawan, Hak Waris Anak Luar Kawin Yang Lahir Dari Perkawinan Campuran Menurut KUHPerdata dan Undang-Undang Nomor 1 tahun 1974, Jurnal Hukum dan Pembangunan tahun ke -42 No. 2, April - Juni 2012.

[4]. Zulfa Djako Basuki, Teori-teori Umum Hukum Perdata Internasional Yang Dapat Mengenyampingkan Berlakunya Hukum Asing. 